\title{
See-saw nystagmus, convergence-retraction nystagmus and contraversive ocular tilt reaction from a paramedian thalamomesencephalic infarct
}

\author{
Bik Ling Man, Yat Pang Fu
}

Department of Medicine and Geriatrics, Tuen Mun Hospital, Hong Kong, Hong Kong

\section{Correspondence to} Dr Bik Ling Man, beli_man@yahoo.com

Accepted 13 November 2014

CrossMark

To cite: Man BL, Fu YP. BMJ Case Rep Published online: [please include Day Month Year] doi:10.1136/ bcr-2014-206851

\section{DESCRIPTION}

A 49-year-old healthy woman presented with sudden onset of binocular diplopia and unsteady gait. Physical examination showed convergence-retraction nystagmus on up-gaze and see-saw nystagmus on left-gaze (video 1). She also had ocular tilt reaction (OTR) with skew deviation, excyclotorsion of the left eye and left head tilt (video 1). Her extraocular eye movements and vestibulo-ocular reflex were normal. Her limb power was full but left lateropulsion was evident during walking. She underwent a brain MRI that revealed a right thalamomesencephalic infarct (figure 1A, B). She made good recovery in 2 months after treatment with aspirin and rehabilitation training.

See-saw nystagmus is characterised by intorsion and elevation of one eye, with synchronous extorsion and depression of the other. ${ }^{1}$ It involves the central otolithic connections, especially in the interstitial nucleus of Cajal (INC). ${ }^{1}$ Convergence-retraction nystagmus in patients with thalamomesencephalic lesion is rare. ${ }^{2}$ This may be related to the damage of supranuclear fibres having an inhibitory effect on the convergence neurons or ischaemia of the divergence neurons in midbrain, which could result in a sustained discharge of medial rectus neurons. ${ }^{2}$ The contraversive OTR is likely due to ischaemia of the INC. ${ }^{3}$

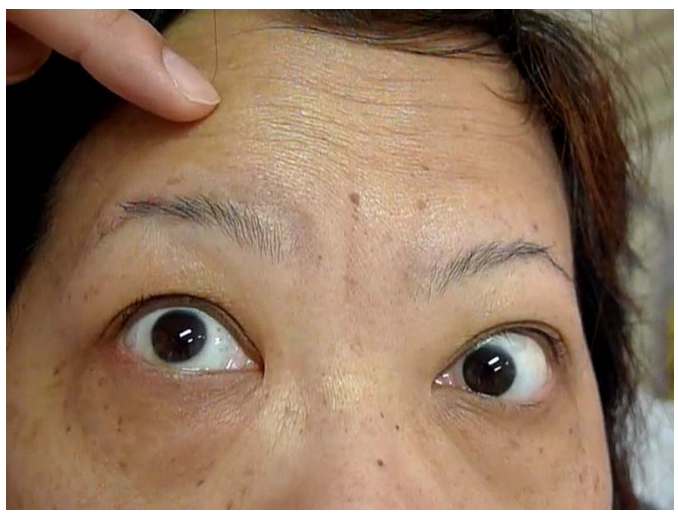

Video 1 Convergence-retraction nystagmus on up-gaze see-saw nystagmus on left-gaze and contraversive ocular tilt reaction.
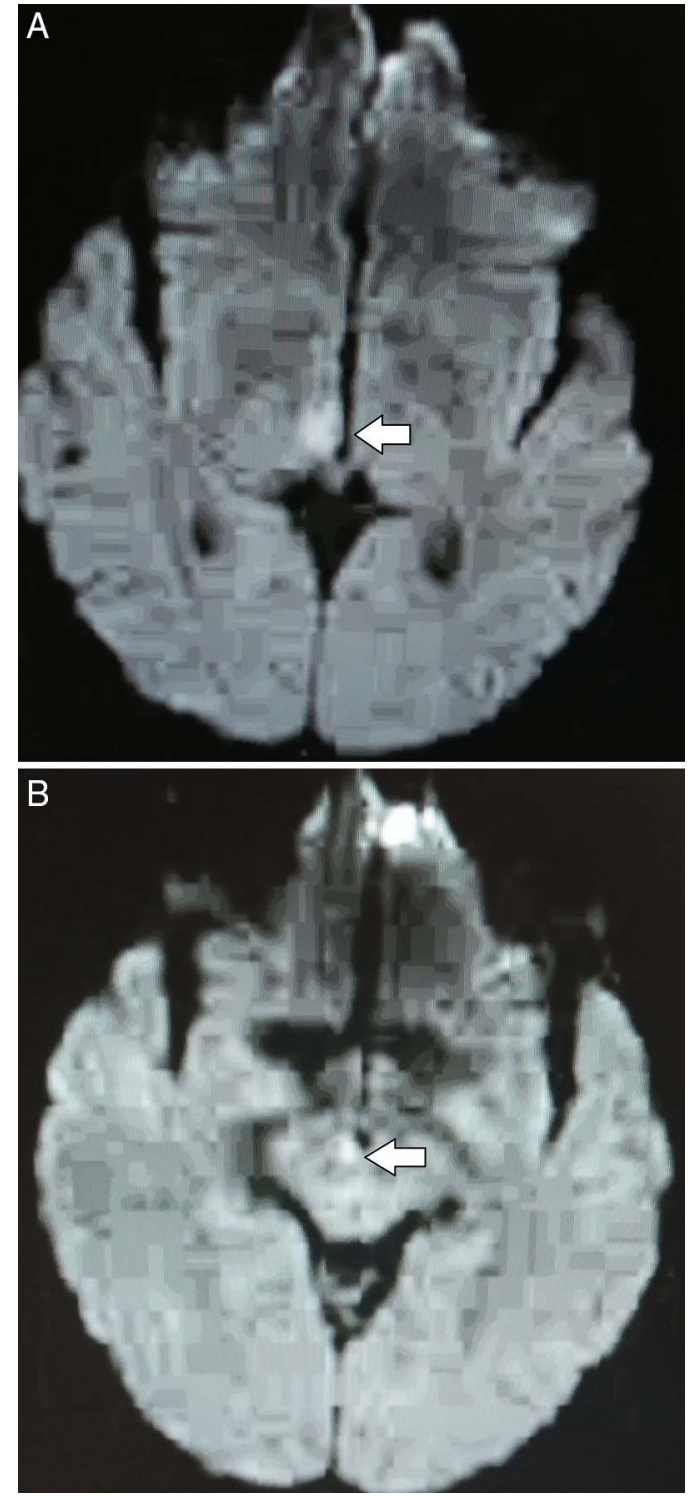

Figure 1 (A) Diffusion-weighted (DW) brain MRI showing a tiny infarct in right thalamus (arrow). (B) DW brain MRI shows a tiny infarct in the right midbrain (arrow). 


\section{Learning points}

See-saw nystagmus is characterised by intorsion and elevation of one eye, with synchronous extorsion and depression of the other. It involves the central otolithic connections, especially in the interstitial nucleus of Cajal (INC).

- Convergence-retraction nystagmus in patients with thalamomesencephalic lesion is rare. This may be related to the damage of supranuclear fibres having an inhibitory effect on the convergence neurons or ischaemia of the divergence neurons in midbrain, which could result in a sustained discharge of medial rectus neurons.

- The contraversive ocular tilt reaction is likely due to ischaemia of the INC.
Competing interests None.

Patient consent Obtained.

Provenance and peer review Not commissioned; externally peer reviewed.

\section{REFERENCES}

1 Halmagyi GM, Aw ST, Dehaene I, et al. Jerk-waveform see-saw nystagmus due to unilateral meso-diencephalic lesion. Brain 1994;117(Pt 4):789-803.

2 Man BL, Fu YP. Acute esotropia, convergence-retraction nystagmus and contraversive ocular tilt reaction from a paramedian thalamomesencephalic infarct. BMJ Case Rep 2014;2014:pii: bcr2014205168.

3 Dieterich $M$, Brandt T. Thalamic infarctions: differential effects on vestibular function in the roll plane (35 patients). Neurology 1993;43:1732-40.

Copyright 2014 BMJ Publishing Group. All rights reserved. For permission to reuse any of this content visit http://group.bmj.com/group/rights-licensing/permissions.

BMJ Case Report Fellows may re-use this article for personal use and teaching without any further permission.

Become a Fellow of BMJ Case Reports today and you can:

- Submit as many cases as you like

- Enjoy fast sympathetic peer review and rapid publication of accepted articles

- Access all the published articles

- Re-use any of the published material for personal use and teaching without further permission

For information on Institutional Fellowships contact consortiasales@bmjgroup.com

Visit casereports.bmj.com for more articles like this and to become a Fellow 